\title{
Station Rotation Method Based on Differentiated Instruction to Improve Higher Order Thinking Skills
}

\author{
Christina Magdalena Soselisa, Rusijono, Bachtiar S. Bachri \\ Department of Educational Technology \\ Universitas Negeri Surabaya \\ Surabaya, Indonesia \\ christina.17070905008@mhs.unesa.ac.id
}

\begin{abstract}
This study is a classroom action research in differentiated classroom, included children with special education needs. Station Rotation is one of teaching methods based on Differentiated Instruction. Station Rotation is a learning method that is able to meet all the children's learning needs and to grow their higher order thinking skills (HOTS) in differentiated classroom. Each student gets the opportunity to explore the Science learning process in various ways (using ICTs, specimen, and other sources) in each station. Through the station rotation method, the students get stimulation to grow their abilities in analyzing, evaluating, and creating. This Classroom action research used One-Group Pre-test-Post-test Design with descriptive quantitative analysis techniques. The research's result showed Station Rotation meets all students' needs (included with mild and middle learning disability) to grow their higher order thinking skills.
\end{abstract}

Keywords-station rotation; higher order thinking; attention deficit disorder; attention deficit with hyperactivity disorder

\section{INTRODUCTION}

In the $2^{\text {nd }}$ grade in Christian Logos elementary school there are some students who have special needs including those who have difficulty in learning, delay in speaking, and concentration disorders in the classroom have difficulty to have higher order thinking skills. The result of their learning in Science were below the average of other students.

So far, a lot of research on station rotation has been done in general classes at the middle and upper secondary levels. This classroom action research aims to improve the ability of higherorder thinking in Science learning in differentiated classes through the station rotation learning method. This study aims to determine how station rotation can improve higher order thinking skills in differentiated classes in the 2nd grade of Elementary LOGOS Christian School. This research was carried out by looking at the reference value of higher order thinking skills in some students who had special needs below the class average, got the mark 40-56 from 0-100. They often followed re-teaching and remedial tests to improve their grades.

Station rotation is one of the blended learning models that combines information and communication technology in learning in traditional classroom [1]. Station Rotation is one of the differentiated learning methods that can meet the learning needs of students [2], including those with special needs. In a dissertation study Apricot Ann Truitt [3], stated that in Station rotation students learning model with joy willing to complete learning activities and demonstrate involvement in learning. This involvement and enthusiasm also builds up in classroom settings because all students are actively involved in their learning. Varied activities have a positive effect on students to access learning material and happily try to find it independently. In the study Truitt [3] states that students easily get many ways to help their learning process. They can discuss with partners in groups when they do not understand a concept. This was also conveyed by Lin, Wong, and Shao (2012) in their study [4].

Station rotation encourages teachers to plan and understand what will be targeted in the class. Then the teacher must be willing to change the plan when it is not in accordance with what the educator students need. Educators must know their students, be flexible (ready for change) and adjust [5]. Differentiated learning is learning that responds to the needs of learners [6]. When these students 'needs are met, they also believe and are proven to be able to improve students' higher order thinking skills [6]. What needs to be considered in differentiated classes, including readiness, student learning styles, cultural backgrounds, including the special needs they have. Children with special needs according to Nordlund include children who have difficulty in language, impaired concentration, unable to control themselves, being impulsive, identified ADD (Attention Deficit Disorder) and ADHD (Attention deficit with hyperactivity disorder), learning disorders (slow learner), cognitive impairments, students with above-average intelligence, and physical abnormalities [7].

Through differentiated learning, teachers can give students value for their unique learning styles [8] by dividing students into small groups based on their needs and by referring to those needs the teacher presents learning to the entire class. This is an example where the Station Rotation model of blended learning is very suitable for differentiated classes [9].

This model is also able to improve student learning outcomes both in class and in greater scope in an institute [10][11]. Higher order thinking skills are defined by several theories according to some experts. The ability to think often uses several frameworks from the theories of experts such as Piaget, Brunner, Bloom, Gagne, Marzano, Glaser, Vygotsky, 
Haladyna, and Safier [12]. The main concepts of higher order thinking processes follow 3 assumptions about thinking and learning. The first assumption, the level of learning cannot be separated from the level of learning. Both of these are mutually involved and dependent, there are many levels of processes and components in it. The second assumption, whether or not the thought process can be learned without the contents of the subject matter will only be a theory. In real life, students will learn the content of learning through experiences gained from community and school, whatever experts conclude, and the concepts and vocabulary they learn in the previous year (prior year) will help them learn higher order thinking skills and content or new material in the following year. Higher order thinking involves the application of a variety of thought processes to complex situations and multi-variable. These variables are contexts, metacognition, procedural knowledge, comprehension, creativity, intelligence, problem solving, and critical thinking.

The highest level of thinking ability at the lowest part is based on the ability to distinguish, application and simple analysis, and cognitive strategies and associate them with content material from prior knowledge (vocabulary, procedural knowledge, and reasoning patters. Stages given by the teacher For students who have special needs, they should not impose a certain framework for them to be able to foster higher order thinking skills [13] but more focused on differentiated learning activities based on student characteristics. Higher order thinking skills including critical, logical, reflective, metacognitive, and creative thinking. The application of these abilities can be successful through validated explanations, decisions, performance, and products based on the context of knowledge and experience and develop well followed by intellectual abilities. The study of Leshowitz, Jenkens, Heaton and Bough (1993) shows that by teaching students who have learning disability about the principles of scientific reasoning through independent inquiry, involving students directly and actively accessing information can improve the critical thinking skills of those students even exceeding regular students who do not get the treatment [14].

Station rotation in its application the teacher must pay attention to the routine activities in the classroom, classroom management, arrange learning and workspace material, instructional consideration, use of technology, logistic of blended learning, and teachers provide clear rules. While students are prepared to participate in activities and interruption to learning. All preparations and activities must be observed, recorded as teacher journals, and the teacher must also prepare questions that provoke higher order thinking skills. Students are given the opportunity to play an active role in the learning process by utilizing technology tools both software and hardware to access learning materials that suit their needs. It is possible that they will find various learning resources needed to dig up information related to the assignments given by the teacher. In station rotation learning which amends the characteristics of assignment students is also defined based on the characteristics of students. Students are also given the freedom to choose the form of performance or project that will be generated from the process of understanding the material that he has explored then presented in the activity [6]. The teacher regulates the rotation of rotation at each station. The teacher prepares stations that specifically provide guidance and individual tutorials conducted in groups regarding the results of exploration of teaching material that has been done together in groups. In the model, there are at least 3 stations. The teacher can design whatever is in the station.

\section{METHOD}

This experimental research is a class action research that has stages of preparation, implementation, observation and reflection [15]. The study used one-group pretest-posttest design and data analysis using descriptive quantitative analysis techniques. Retrieval of data through interviews, observations, teacher journal notes, and student learning outcomes tests. The instruments used are rubric performance, observation sheets, summative and formative questions. The subject of this study is $2^{\text {nd }}$ Grade Logos Christian Elementary School totaling 17 students with various characteristics including students with speech delay, short span attention problems, and learning difficulties.

\section{RESULTS AND DISCUSSION}

\section{A. Preparation}

The teacher provides clear rules and conducts classroom management of activities, time allocation, seating arrangement, formation of (heterogeneous) student work groups with various characteristics and diverse cognitive abilities. There are 4 groups of 4-5 students per group. The teacher determines the objectives and objectivity of learning and talks with students at the beginning of learning. Students are given the opportunity to determine the performance and projects to be presented. The teacher prepares 3 stations, including 1) ICT Station which is equipped with laptops, LCD Screen, as well as supplementary books to access information both online and offline under the supervision of the teacher. The offline information provided is videos and articles on bone types in humans, 2) Mini laboratory stations that have chicken and cow bones to study the types of bone forms (flat bone, long bone, short bone and irregular bone). ) as a bridge to understanding bone shape in humans. At this station there is also a human skeleton torso. 3) Teacher station where students can consult with the teacher as well as the teacher also conduct joint analysis and evaluation of the results of student exploration. Students get the opportunity to ask questions and correct mistakes. The teacher can supervise and accompany the extent to which students complete the work and project tasks that have been chosen as a form of student implementation and creativity after understanding the material that was explored together in the work group. This is as stated by Tomlinson (2001) that teachers must respond to students' learning needs and flexibly change what learning plans are needed by students.[6]

\section{B. Implementation}

The teacher provides an explanation of the learning objectives and time limits along with the rules that are treated in each station. Students do all the shared provisions that have been explained by the teacher how they carry out the process of learning Science. The Science class has duration of 80 minutes in each meeting. 20 minutes at the beginning the teacher gives a written pretest to know the prior knowledge needed before 
studying the material about human bones. The teacher explains in a classical beginning the human bones in general and asks a number of questions and gives clear assignments so that students understand well what to do with the working group. Each group has 15 minutes to access each station. 15 minutes at the end of learning the teacher provides an opportunity for each group to explain the results of their exploration of learning by answering assigned questions and the extent of the development of project preparation they have been working on.

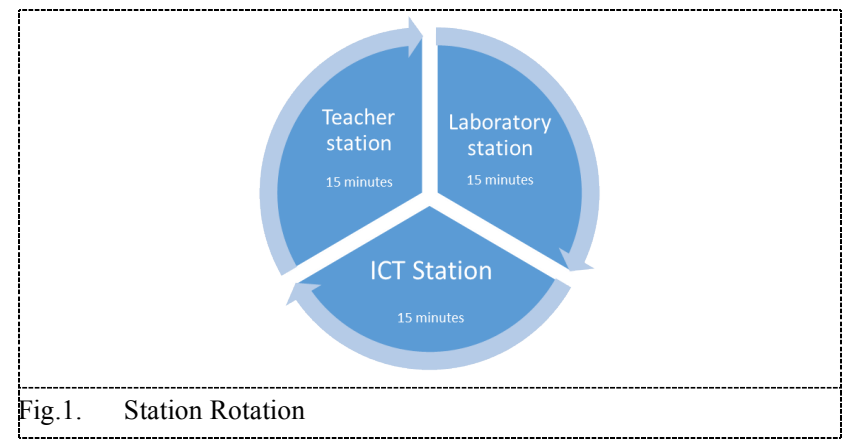

\section{Observation}

At the end of the meeting the teacher must have awareness to the learning needs of students when learning takes place. In this first cycle the teacher heard student complaints that they lacked time in preparing their assignments. In this stage students were also able to analyze their learning needs and how they learn to manage their activities as well as possible in a way together in work groups. They suggested for the next meeting the teacher should give them time to complete the project without having to rotate in each station. However, they want the time with the teacher at the station rotation to still be given 15 minutes in turn. They felt that on the first day there had been a lot of information obtained from ICT Station and Mini laboratory Station. They also asked the teacher's willingness to lend supplementary books to be borrowed by the group.

The students learning outcomes shows a good result. The students were able to perform their understanding by analyzing the problem in written test, integrate all the information to present them creatively.

A student with speech delay in expressing his opinion when identifying the type of bone, why the bone is called long bone gave his idea. At that time the teacher also provided an opportunity for him to explain in a way that he could. He was able to explain by describing why the bone was called long bone by describing two types of bones, namely long bone and short bone, he also explained it with his body language. The teacher reiterates how to pronounce verbally with simple sentences so that he repeated and communicated his idea verbally. The interesting thing in this station rotation method is that the student accessed his learning material thru video that he watched repeatedly about identifying bone types. In fact, he has the ability to explain why long bone is in the fingers, arms, calves, and legs. He replied that strong long bone held the body weight. He explained it in sign language. He got his understanding by using torso to differ long bone from short bone. His understanding helped him to identify both, even though long bone is in the same size as short bone. At this stage,
He simply showed his higher order thinking skill in identification, analysis, and reasoning.

$\mathrm{L}$ and $\mathrm{J}$ who have a concentration disorder are helped by the formation of small groups that are given the opportunity to access learning resources that are appropriate to their learning style. The L and J students were very fond of describing what he saw and remembering it easily even describing the skeleton of the human body as a whole and identifying the type of bone and then correlating the shape of the bone to the function of the bone. In fact, he had no difficulty to identify upper skull bone which is a flat bone even though it's shaped like a bowl. The students found difficulty to distinguish them. By seeing and touching the original object, they understood the flat bone is a flat and extends in any shape, whether flat or curved.

There were also some students who are above the average ability, they are patient enough in guiding their friends who have difficulties by explaining and guiding their friends to be able to understand the types of bones. They also provided brilliant ideas for making human skeletons from plastic straws. The group's performance was in the form of presentations, puppet shows, posters, and exhibits on bones made from cardboard paper resembling the shape of a bone.

Higher order thinking skills can be grown through activities in this station rotation. Station rotation is differentiated instruction that is able to accommodate students' learning needs in differentiated classroom with children who have special needs.

\section{Reflection}

The stages given by the teacher to students who have special needs should not impose a particular framework for them to foster higher order thinking skills [13] but are more focused on differentiated learning activities based on the characteristics of students.

From the first cycle that was carried out it can be seen the results of learning with the station rotation model, students have ways from the simple to the complex to be creative in expressing or showing the results of the exploration of learning that they have done in each station. This is as expressed by Truitt [3] Higher order thinking involves the application of a variation of the thinking process in complex situations and has a multi variable. These variables are contexts, metacognition, procedural knowledge, comprehension, creativity, intelligence, problem solving, and critical thinking. The application of these capabilities can be successful through explanations, decisions, performance, and products that are validated based on the context of knowledge and experience and developing well followed by intellectual abilities.

Learning outcomes from the application of the Station rotation method showed significant results. These learning outcomes are certainly a combination of performance appraisal (planning, integrating information, and packaging it creatively both in various forms of performance), student creativity in producing projects, and written tests. Students have an average high-order thinking skill with a value between 70-100 from a scale of 0 to 100 . 


\section{CONCLUSION}

The application of Station rotation in differentiated classes is able to foster higher order thinking skills in students, including students with special needs, including delays in speech, impaired concentration, and learning difficulties. Station rotation is able to meet the diverse learning needs of students. Of course the application of this learning method must be done with very good preparation and the teacher must. be ready to change flexibly to see the needs of students during the learning process takes place. When students 'learning needs are met and they have the opportunity to explore, create and experiment, these things grow and grow students' higher-order thinking skills, both for those who have special needs.

\section{REFERENCES}

[1] C. M. Christensen, M. B. Horn, and H. Staker, "Is K-12 blended learning disruptive: An introduction of the theory of hybrids," 2013, 2013.

[2] C. P. Lin, L. H. Wong, and Y. J. Shao, "Comparison of 1:1 And 1:M CSCL environment for collaborative concept mapping," J. Comput. Assist. Learn., 2012

[3] A. A. Truitt, "A case study of the Station Rotation blended learning model in a third grade classroom," ProQuest Diss. Theses, 2016.

[4] J. H. Rivera, "The Blended Learning Environment: A Viable Alternative for Special Needs Students," J. Educ. Train. Stud., 2017.

[5] K. E. Y. Aspects, O. F. Blended, and L. Program, "Proof Points : Blended
Learning Success in School Districts," Proof Points, 2014.

[6] C. A. Tomlinson, How TO Differentiate instruction in mixed-ability classrooms. 2001.

[7] M. Nordlund, Differentiated instruction: meeting the educational needs of all students in your classroom, vol. 41, no. 06. 2004.

[8] M. Bagby, "The flipped approach: Past research, practical applications, and experiences in K-12 science and math classrooms," in Flipped Instruction: Breakthroughs in Research and Practice, 2017.

[9] M. B. Horn and H. Staker, "What is blended learning," Blended Using disruptive Innov. to Improv. Sch., 2017.

[10] K. Kafer, "School District Partnerships Help Colorado K-12 Blended Learning Take Flight," IndependenceInstitute.org, no. July, 2014.

[11] J. S. Haas, "Change leadership practices for effective implementation of alternative breakthrough models in blended and online learning at select K-12 schools: A phenomenological study," 2018.

[12] F. J. King, L. Goodson, and R. Faranak, "Higher order thinking skills: Definition, teaching strategies and assessment," 2004.

[13] C. A. Tomlinson and J. Mctighe, Integrating differentiated instruction and understanding by Design. 2006.

[14] B. Leshowitz, K. Jenkens, S. Heaton, and T. L. Bough, "Fostering critical thinking skills in students with learning disabilities: an instructional program.," J. Learn. Disabil., 1993.

[15] S. Kemmis and R. McTaggart, "The Action Research Reader, 3rd edn, Geelong," Victoria Deakin Univ. Press, 1988. 